\title{
Population Dynamics of Greenland Halibut in the Gulf of St. Lawrence
}

\author{
W. R. Bowering \\ Department of Fisheries and Oceans, Fisheries Research Branch \\ Northwest Atlantic Fisheries Centre, P. O. Box 5667 \\ St. John's, Newfoundland, Canada A1C 5X1
}

\begin{abstract}
Greenland halibut, Reinhardtius hippoglossoides, in the Gulf of St. Lawrence are generally concentrated during the winter in deep water of the Laurentian Channel off Southwest Newfoundland. They are dispersed during the summer, but small concentrations are found in the mouth of the St. Lawrence River west of Anticosti Island. The fishery for this species in the Gulf increased rapidly from 1,500 tons in 1975 to nearly 9,000 tons in 1979 and declined to 3,000 tons in 1981, the catches being comprised of age-groups corresponding to those of very successful year-classes off Labrador and eastern Newfoundland. The drastic reduction in abundance since 1978, the lack of observable recruitment, the recent decline in catches, and peculiarities in certain biological characteristics indicate that substantial recruitment to the fishery in the Gulf of St. Lawrence may come from areas outside the Gulf, possibly through the Strait of Belle Isle.
\end{abstract}

\section{Introduction}

Small quantities of Greenland halibut have generally been caught during research vessel surveys in the Gulf of St. Lawrence (Templeman, 1973). Their presence appeared to be limited by the shallow depth of the cold $\left(<0^{\circ} \mathrm{C}\right)$ water layer which is considered unfavorable and tends to restrict their distribution. Incidental catches in gillnets and Danish seines were generally less than 1,000 tons annually until 1974 , after which there was a rapid increase to nearly 9,000 tons in 1979 . This increase in catch in the Gulf of St. Lawrence followed the recruitment of several strong year-classes similar to those which produced a lucrative fishery off Labrador and eastern Newfoundland (Bowering, MS 1980).

There is very little information on the biology of Greenland halibut in the Gulf of St. Lawrence except that accruing incidentally from investigations on other species. Bowering (1978) briefly described the growth pattern of this species in the Gulf of St. Lawrence as part of a broader study of growth patterns throughout the Northwest Atlantic. In a later paper, the fecundity of Greenland halibut in the Gulf was compared to that in fish taken off southern Labrador (Bowering, 1980). Most studies concerning Greenland halibut in the Gulf have, however, been related to stock identification. Templeman (1970), using meristic characteristics, Fairbairn (1981), using biochemical techniques, and Khan et al. (1982), using parasites as biological tags, have all concluded that the Gulf of St. Lawrence contains a self-sustaining population of Greenland halibut. This paper presents information on the distribution, biology and fishing of Greenland halibut in the Gulf of St. Lawrence, based mainly on observations during 1976-81.

\section{Materials and Methods}

Data on distribution and abundance of Greenland halibut in the Gulf of St. Lawrence during 1976-81 were obtained from bottom-trawl surveys in winter (January-February) by the research vessel Gadus Atlantica in 1978-81 and in summer (mainly August) by the chartered trawlers Beothic Venture in 1976 and 1978-80 and Vicki and Brothers in 1981. The winter surveys were conducted with an Engels 9 High-rise No. 164 bottom-trawl and the summer surveys with a Yankee No. 36 shrimp trawl, both gears having a codend liner with mesh size (stretched) of $12 \mathrm{~mm}$. Each trawl set lasted $30 \mathrm{~min}$. Catches were recorded by number and weight $(\mathrm{kg})$ for each species caught.

An indication of the distribution and abundance of Greenland halibut during the winter and summer surveys was obtained by calculating, for hauls with no gear damage, the average weight per set in quadrangles of $30^{\prime}$ latitude $\times 60^{\prime}$ longitude. The analyses are based on 454 successful sets during the four winter surveys in 1978-81 and 635 sets during the five summer surveys in 1976-81 (Fig. 1).

For each catch of Greenland halibut during the winter surveys, measurements included fork length (nearest centimeter, snout to the ends of the middle rays of the caudal fin) and the total body weight (g). Observations on sexual maturity were made and otoliths were collected for ageing from stratified samples of the catches.

Otoliths used for ageing were ground with an emery stone on the convex surface to expose the nuclei clearly, placed in a black watchglass containing 


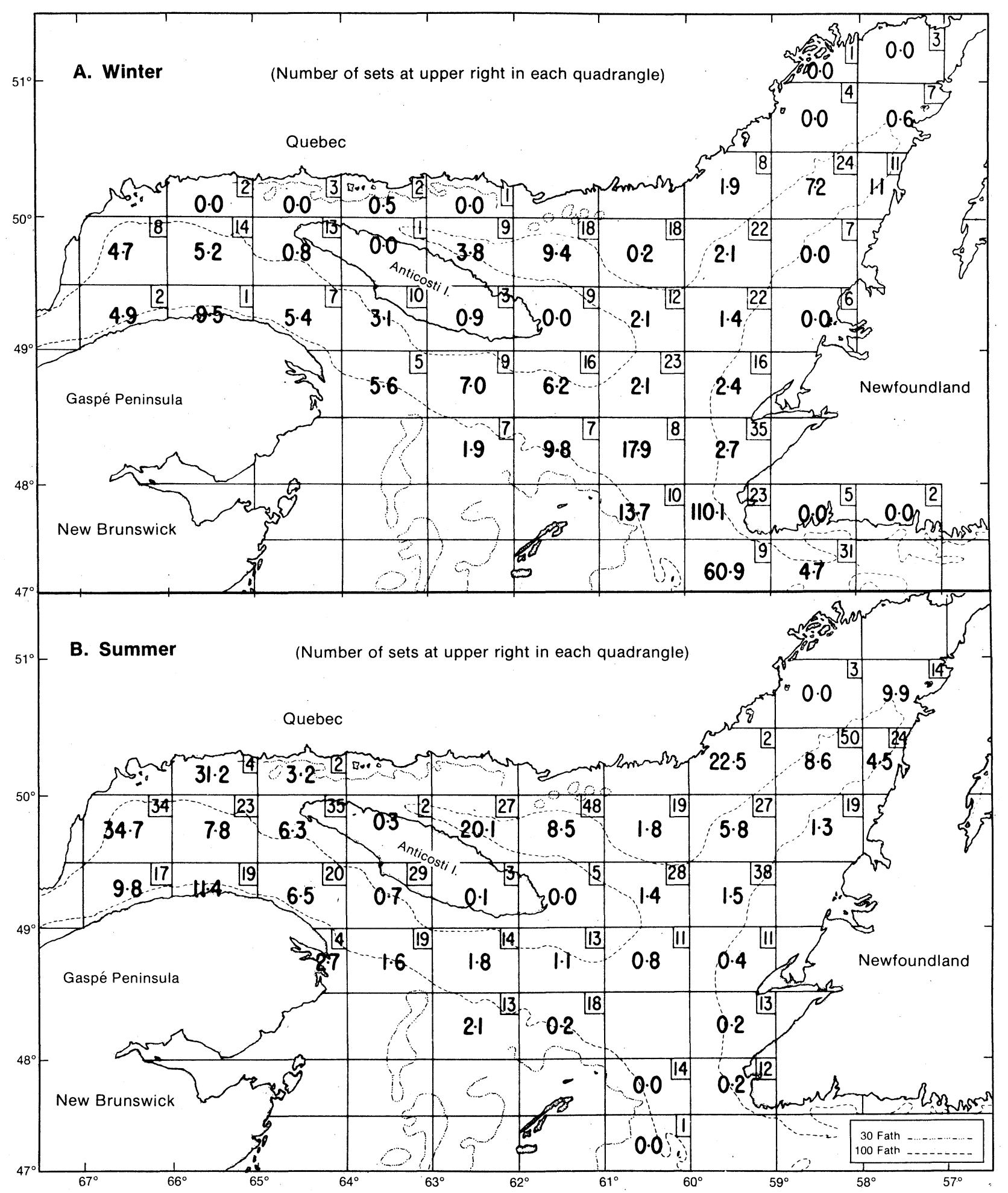

Fig. 1. Average catches $(\mathrm{kg})$ of Greenland halibut per 30-min set in the Gulf of St. Lawrence from bottom trawl surveys $(\mathbf{A})$ in the winters of $1978-81$, and (B) in the summers of 1976-81.

ethanol and examined by reflected light with a binocular microscope. Only the left otoliths were used for ageing, because the annuli were more evenly spaced and more distinct. Growth curves were determined from linear regressions of mean length on logarithm of age, similar to the method used by Bowers (1960) for witch flounder, Glyptocephalus cynoglossus, and emphasized by Roff (1980). The power function ( $Y=$ $\left.a X^{b}\right)$ was used to compute the weight-length relationships. Maturity ogives and mean length at $50 \%$ maturity 
values were determined by the "probit transformation" method described by Fisher and Yates (1953), first applied to determine age at $50 \%$ maturity in fish by Flemish (1960), and used subsequently for different species by Pitt (1966), Bowering (1976) and Templeman et al. (1978).

Nominal catches of Greenland halibut in the Gulf of St. Lawrence during 1966-81 were derived from Statistical Bulletins of ICNAF (International Commission for the Northwest Atlantic Fisheries) for 1966-78 and of NAFO for 1979-81. Age compositions of commercial catches of Greenland halibut were based on sampling the winter fishery in NAFO Division 4R by Newfoundland trawlers in 1979 and 1980.

\section{Results and Discussion}

\section{Distribution and abundance}

The results of the winter surveys in 1978-81 indicate that, although Greenland halibut were distributed widely throughout the Gulf of St. Lawrence, they were generally not very abundant except in the deep water in Cabot Strait at the southeastern entrance to the Gulf (Fig. 1A), where the average catch per trawl set was 110 $\mathrm{kg}$ in one unit area and $61 \mathrm{~kg}$ in another. Away from the entrance to the Gulf, the average catch per set did not exceed $10 \mathrm{~kg}$ in any other unit area, and catches in very few unit areas exceeded an average of $5 \mathrm{~kg}$ per set. The results of the summer surveys in 1976-81 indicate quite a different pattern of abundance (Fig. 1B), with the largest mean catches per set ( 35 and $31 \mathrm{~kg}$ ) in the mouth of the St. Lawrence River and somewhat lower concentrations ( 20 and $23 \mathrm{~kg}$ per set) north of Anticosti Island and on the northern side of the Esquiman Channel. Although two important unit areas off southwestern Newfoundland were not sampled during the summer surveys, comparable catch rates in the surrounding unit areas indicated very low abundance of Greenland halibut in the region.

Estimates of minimum trawlable biomass of Greenland halibut from the winter surveys, based on the standard stratified-random sampling design (Doubleday, 1981), indicate a rapid decrease in stock size from 1978 to 1981 (Table 1). Despite the lack of an estimate for the western part of the Gulf (Div. 4S) in 1979 due to incomplete coverage of the area, the available data indicate a decrease in biomass by about $52 \%$ from 1978 to 1980 and by 55\% from 1980 to 1981 .

In the winters of 1978 and 1979, Greenland halibut were concentrated in Stratum 802 (Table 1), and the biomass estimates were consequently higher in Div. $4 R$ than in Div. 4S in 1978 and presumably also in 1979. However, the relatively high catch rate in Stratum 803 (the largest of the Gulf strata) in 1980, when adjusted to

TABLE 1. Result of stratified-random bottom-trawl surveys in the Gulf of St. Lawrence, 1978-81. (Strata numbers as in Doubleday, 1981.)

\begin{tabular}{|c|c|c|c|c|c|c|c|c|c|}
\hline \multirow{2}{*}{$\begin{array}{l}\text { NAFO } \\
\text { Div. }\end{array}$} & \multirow{2}{*}{$\begin{array}{l}\text { Stratum } \\
\text { number }\end{array}$} & \multicolumn{4}{|c|}{ Average number per set } & \multicolumn{4}{|c|}{ Average weight per set $(\mathrm{kg})$} \\
\hline & & 1978 & 1979 & 1980 & 1981 & 1978 & 1979 & 1980 & 1981 \\
\hline \multirow[t]{14}{*}{$4 \mathrm{R}$} & 801 & 17.7 & 14.7 & 19.0 & 6.0 & 25.0 & 15.0 & 14.8 & 9.3 \\
\hline & 802 & 257.0 & 246.0 & 56.7 & 41.0 & 420.2 & 368.2 & 96.1 & 78.5 \\
\hline & 809 & 2.9 & 5.7 & 0.7 & 2.5 & 5.2 & 9.4 & 0.7 & 7.5 \\
\hline & 810 & 29.7 & 3.0 & 2.8 & 0.0 & 48.9 & 5.5 & 6.1 & 0.0 \\
\hline & 811 & 0.0 & 0.6 & 0.5 & 0.0 & 0.0 & 0.6 & 0.7 & 0.0 \\
\hline & 812 & 5.0 & 2.0 & 0.7 & 0.3 & 6.2 & 3.5 & 0.1 & 0.2 \\
\hline & 813 & 1.0 & 2.8 & 1.5 & 0.3 & 0.9 & 2.4 & 0.7 & 0.3 \\
\hline & 814 & 1.3 & 1.7 & . - & - & 1.4 & 2.7 & - & - \\
\hline & 820 & 0.0 & 0.0 & 0.0 & 0.0 & 0.0 & 0.0 & 0.0 & 0.0 \\
\hline & 821 & 0.0 & 0.0 & 0.0 & 0.0 & 0.0 & 0.0 & 0.0 & 0.0 \\
\hline & 822 & 0.0 & 0.0 & 0.0 & 0.0 & 0.0 & 0.0 & 0.0 & 0.0 \\
\hline & 823 & 0.0 & 0.0 & 0.3 & - & 0.0 & 0.0 & 1.1 & - \\
\hline & 824 & - & - & 0.5 & 0.0 & - & - & 0.2 & 0.0 \\
\hline & 825 & 0.0 & 0.0 & 一 & - & 0.0 & 0.0 & - & - \\
\hline \multirow[t]{9}{*}{$4 S$} & 803 & 17.5 & - & 24.4 & 5.5 & 21.1 & - & 32.1 & 8.8 \\
\hline & 804 & 19.3 & - & 17.0 & 2.7 & 18.9 & - & 16.3 & 4.6 \\
\hline & 805 & 12.6 & - & 19.7 & 7.1 & 12.7 & - & 18.6 & 7.8 \\
\hline & 806 & 4.7 & - & 3.3 & 1.3 & 5.5 & - & 3.9 & 2.1 \\
\hline & 807 & 5.3 & 2.0 & 2.0 & 0.0 & 7.1 & 3.0 & 3.5 & 0.0 \\
\hline & 808 & 2.3 & 2.3 & 1.0 & 1.0 & 3.9 & 1.8 & 1.7 & 1.2 \\
\hline & 815 & 6.7 & 1.5 & 2.7 & 0.4 & 4.7 & 1.0 & 2.3 & 0.4 \\
\hline & 816 & 46.4 & 10.3 & 3.7 & 0.7 & 33.7 & 6.5 & 2.3 & 0.6 \\
\hline & 819 & 0.5 & 0.0 & 0.3 & 0.0 & 0.6 & 0.0 & 0.3 & 0.0 \\
\hline \multirow{3}{*}{\multicolumn{4}{|c|}{ Minimum trawlable biomass (tons): }} & \multicolumn{2}{|c|}{ Div. 4R } & 14,984 & 12,477 & 3,502 & 2,888 \\
\hline & & & & \multicolumn{2}{|c|}{ Div. $4 \mathrm{~S}$} & 9,263 & $\cdots$ & 9.079 & 2.836 \\
\hline & & & & \multicolumn{2}{|c|}{ Total: } & 24,247 & $\ldots$ & 12,581 & 5,724 \\
\hline
\end{tabular}


total area, resulted in an overall larger biomass estimate for Div. 4S than Div. 4R. In 1981, the biomass estimates were similar for both divisions. A few strata in Div. $4 R$ were not surveyed every year, but these were not considered to be significant in the calculations of biomass.

These areas of high density are mainly prespawning locations where temperature conditions are considered conducive to spawning. Similar prespawning concentrations of witch flounder, Glyptocephalus cynoglossus, and cod, Gadus morhua, have been found in the same general location (Bowering and Misra, 1982; Lussiaa-Berdou, MS 1979). After spawning, the concentrations disperse mostly toward the western part of the Gulf, where there are localized concentrations of northern prawn, Pandalus borealis, on which they feed during the summer (Tremblay and Axelsen, MS 1981).

Length distributions of Greenland halibut from three depth zones $(185-275,276-366$, and $>366 \mathrm{~m})$ show a clear increase in fish size with depth for both sexes (Fig. 2). The mean length of females was consistently greater than that for the males in all depth zones, the differences being greatest in depths greater than $366 \mathrm{~m}$ (Table 2). Females were more abundant than males in the two shallower depth zones, the ratio being about 60:40 in each case, but the reverse situation was observed in samples from the deepest zone. The increase in size with depth is characteristic of Greenland halibut in other areas of the Northwest Atlantic. Bowering (1978) showed a clear increase in average size with increasing depth to $1,000 \mathrm{~m}$ for Greenland halibut off Labrador, and indicated that, upon approaching maturity, they migrate to spawning grounds in deep water. The reversing of the sex ratios may also be related to maturation. Because males mature at an earlier age and smaller size than females, the proportion of males found in the deepest zone where spawning presumably occurs would be expected to be higher than that of females.

\section{Recruitment}

Male Greenland halibut, sampled during the winter surveys of 1978-81, ranged in age from 3 to 10 years, but the catches consisted primarily of agegroups 6-8 (Fig. 3). Although sampling was consistent from year to year, the average number per set decreased markedly during 1978-81, and no fish older than 8 years (except in 1980) were sampled. The ages of female Greenland halibut ranged from 3 to 12 years, but the catches in all 4 years consisted mainly of agegroups 6-9, the prevalence of which increased from 1978 to 1979 and then decreased substantially in 1980 and 1981.

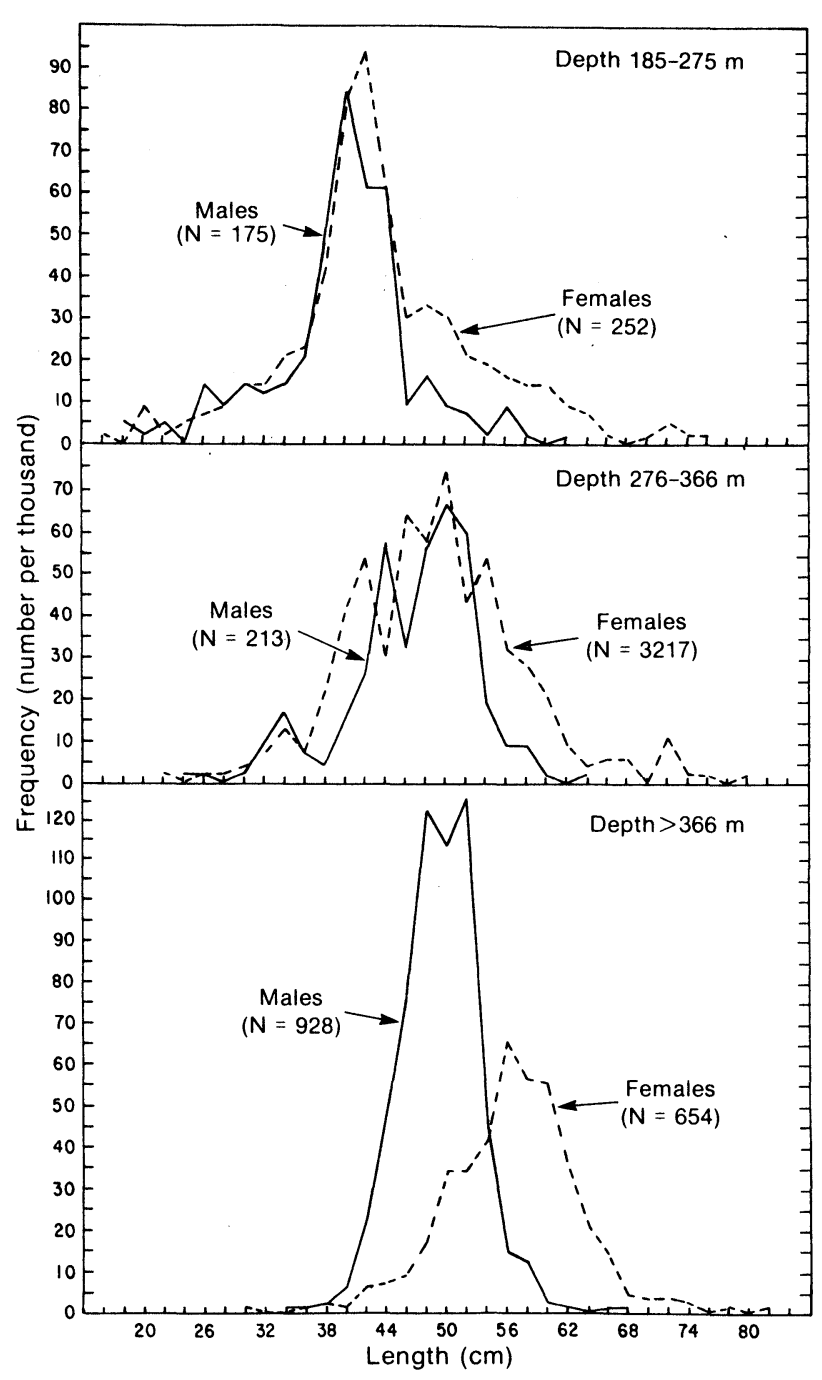

Fig. 2. Length distributions of male and female Greenland halibut in the Gulf of St. Lawrence by depth zones from the 1978-81 winter surveys.

TABLE 2. Mean length and sex ratio by depth zone for Greenland halibut in the Gulf of St. Lawrence.

\begin{tabular}{cccccc}
\hline \hline \multirow{2}{*}{$\begin{array}{c}\text { Depth } \\
\text { zone } \\
(\mathrm{m})\end{array}$} & \multicolumn{2}{c}{ Mean length $(\mathrm{cm})$} & & \multicolumn{2}{c}{ Sex ratio } \\
\cline { 2 - 3 } \cline { 5 - 6 } & Male & Female & & Male & Female \\
\hline $185-275$ & 40.3 & 44.2 & & 41.0 & 59.0 \\
$276-366$ & 47.2 & 51.5 & & 39.9 & 60.1 \\
$>366$ & 49.8 & 56.9 & & 58.7 & 41.3 \\
\hline
\end{tabular}

There was a substantial increase in abundance of commercial-sized Greenland halibut in the Gulf of St. Lawrence in the late 1970's due to the appearance of strong year-classes coincident with those found in the Labrador and eastern Newfoundland areas (Bowering, MS 1980). The peristent scarcity of small Greenland halibut in the catches during the winter surveys (Fig. 2, 3 ), despite the demonstrated capability of the Gadus 


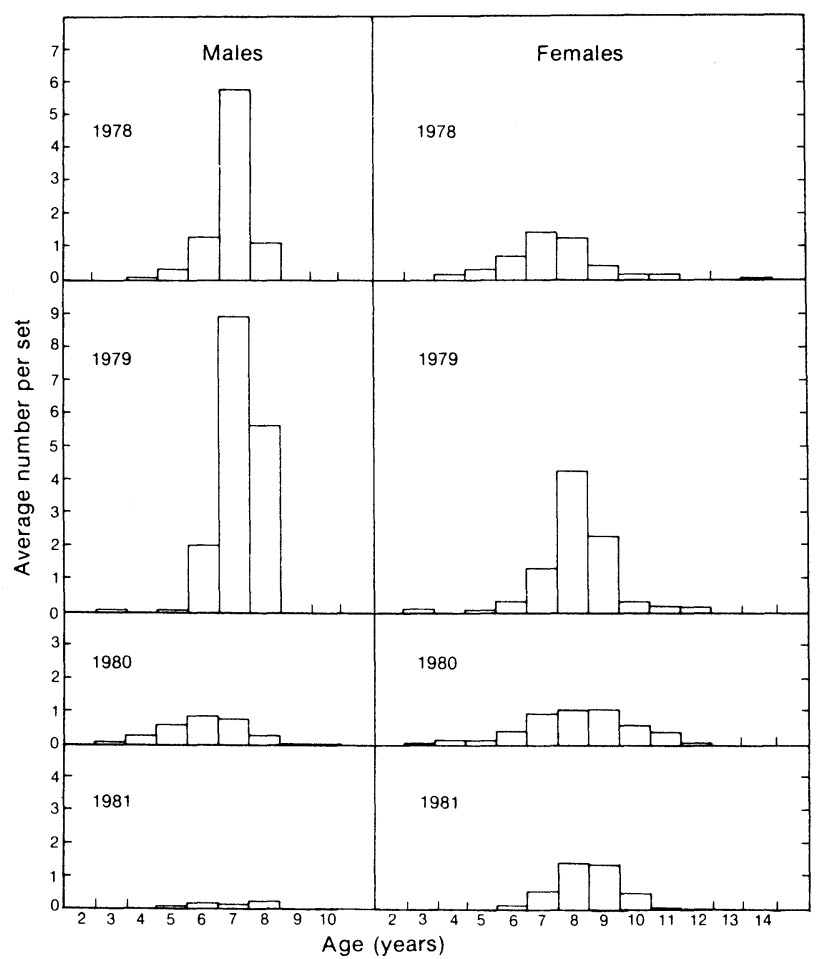

Fig. 3. Age distributions of male and female Greenland halibut in the Gulf of St. Lawrence by year from the 1978-81 winter surveys.

Atlantica's research trawl in catching small Greenland halibut off eastern Newfoundland (Bowering and Brodie, MS 1981), indicates that little recruitment may come from the presence of these strong year-classes in the Gulf. It is also evident from the age frequencies (Fig. 3) that Greenland halibut disappeared from the Gulf very abruptly at relatively young ages. Furthermore, the recent recruitment to the fishery in the Gulf was much higher than could be expected from the standing stock of mature fish in the area. In the absence of significant abundance of Greenland halibut off southern Newfoundland near the southern entrance to the Gulf, it is postulated that the rather sudden increase in abundance of this species in the Gulf during the late 1970's resulted from immigration through the Strait of Belle Isle of large numbers from the strong year-classes prevalent on the Labrador shelf. The sudden disappearance of older fish was probably due to their emigration from the Gulf upon approaching maturity. Fairbairn (1981), from electrophoretic analysis, concluded that the Greenland halibut stock in the Gulf of St. Lawrence is a separate breeding stock with some gene flow (migration) between the Gulf and Northeast Newfoundland stocks, probably through the Strait of Belle Isle.

\section{Growth}

Semi-logarithmic growth curves, fitted to mean length-at-age data for male and female Greenland hali-
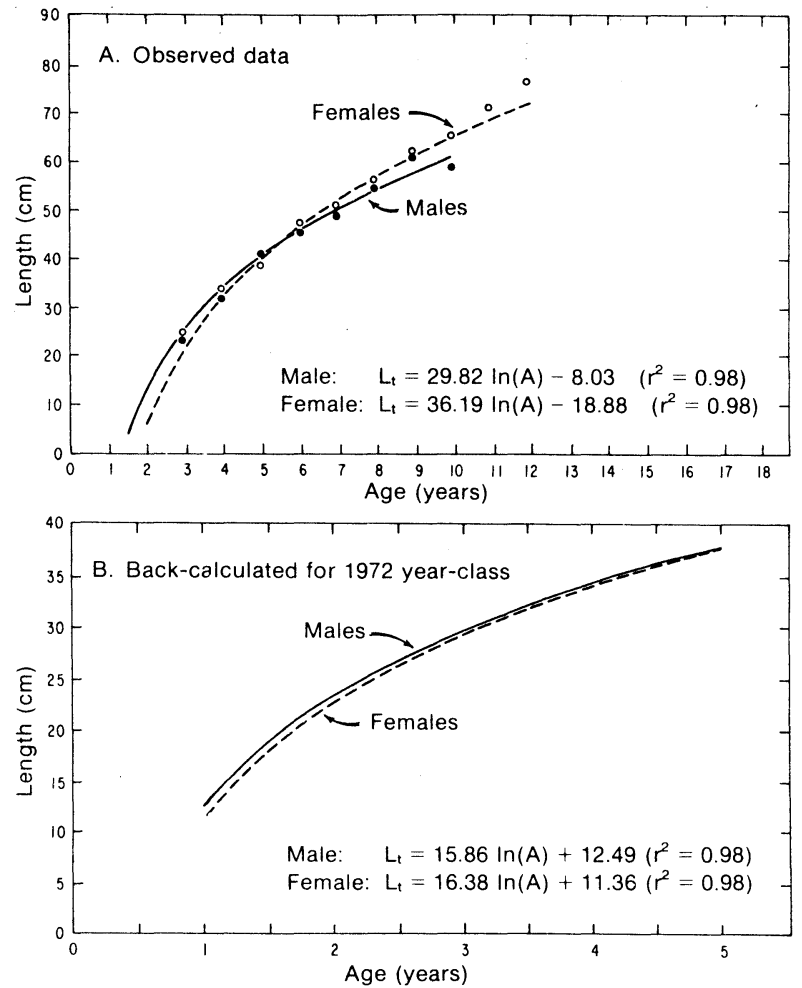

Fig. 4. Growth curves for male and female Greenland halibut in the Gulf of St. Lawrence from (A) observed length-at-age data obtained during the 1978-81 winter surveys, and (B) backcalculated length-at-age data based on measurements of otoltins from fish of the 1972 year-class.

but, indicate that females grow faster than males beyond age 7 (Fig. 4A). The presence of females up to age 12 and males only to age 10 in the samples indicates that females may live longer than males. No Greenland halibut younger than age 3 were taken during the winter surveys and very few 3 - and 4-year old fish were sampled. Consequently, an impression of the growth pattern of the younger age-groups was determined by back-calculation of fish lengths up to age 5 from measurements of otolith annuli for 30 males and 30 females of the 1972 year-class (Fig. 4B). A covariance analysis indicated no significant difference between the slopes or elevations of the regression lines, and hence no difference between sexes in growth rate or mean size-at-age up to age 5 .

Weight-length relationships of the form $W=a L^{b}$ were fitted to measurements of male and female Greenland halibut sampled during the winter surveys (Fig. 5). The regressions are not significantly different statistically, and the high level of correlation between length and weight (logarithmically transformed) indicates that growth is isometric over the size range of fish sampled. The regression coefficients are sufficiently close to 3.0 that body weight can be considered as proportional to the cube of length for Greenland halibut in the Gulf of St. Lawrence. 


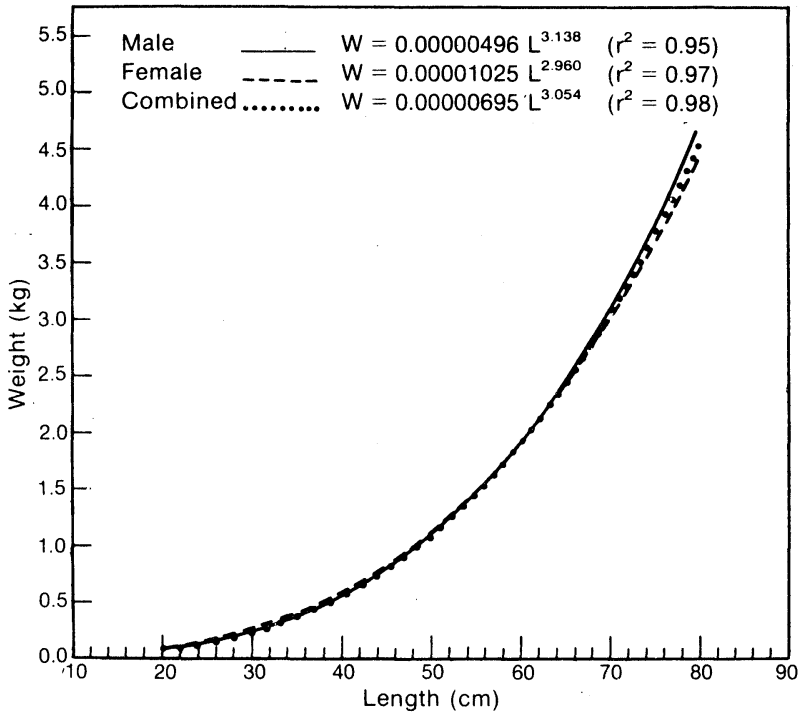

Fig. 5. Length-weight relationships for male and female Greenland halibut in the Gulf of St. Lawrence from measurements during the 1978-81 winter surveys.

\section{Sexual maturity}

Maturity ogives for Greenland halibut from the Gulf of St. Lawrence (Fig. 6) indicate that males become sexually mature at considerably smaller sizes than females, the $50 \%$ maturity lengths being 39.8 and $55.9 \mathrm{~cm}$ respectively. Corresponding ages at sexual maturity, calculated from the growth curves, were 5.0 years for males and 7.9 years for females. However, these estimated ages at $50 \%$ maturity may not be precise due to considerable variation of the percent mature values about the maturity curves.

Pecularities in the maturity ogives (Fig. 6) may be explained by the mixture of Greenland halibut from the Gulf of St. Lawrence and Labrador-eastern Newfoundland stocks. The levelling-off of the percentages mature at about $80 \%$ for males occurs over the length range of $46-54 \mathrm{~cm}$ which corresponds approximately to the average size of the strong year-classes (Fig. 3,4), and probably represents the addition of large numbers of immature fish of these sizes and ages. Similarly for females, the levelling-off at about $80 \%$ indicates the influx of immatures of sizes (and ages) corresponding to the strong year-classes. This effect would be expected if immature immigrants contributed significantly to the samples at these sizes, because Greenland halibut are known to mature at larger sizes in the Labrador-eastern Newfoundland area than in the Gulf of St. Lawrence (Bowering, 1983).

\section{Commercial fishery}

Nominal catches of Greenland halibut in the Gulf of St. Lawrence ranged from about 400 to 1,000 tons during 1966-74, increased steadily to 4,000 tons in 1977, more than doubled to nearly 9,000 tons in 1979 , and declined to about 3,000 tons in 1981 (Table 3).

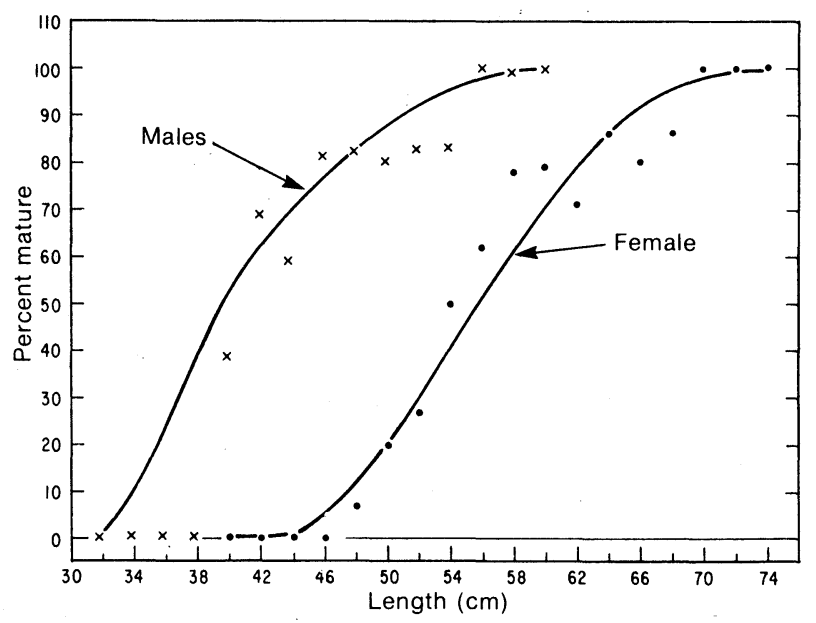

Fig. 6. Length-maturity ogives for Greenland halibut in the Gulf of St. Lawrtence, from observations during the 1978-81 winter surveys.

Until 1979, more of the fish were caught in Div. 4S, by vessels from Quebec, than in the other two divisions. In 1979 and 1980, the fishing pattern changed, with considerably higher catches in Div. 4T (off Gaspé) by Quebec fishermen and also in Div. 4R by Newfoundland vessels. The lower catches in 1981, especially in Div. $4 \mathrm{R}$ and $4 \mathrm{~S}$, were due to the prohibition of large trawlers from fishing for cod in the Gulf of St. Lawrence where substantial quantities of Greenland halibut and witch flounder were usually taken as by-catch in the cod fishery.

Age frequencies of Greenland halibut in samples from the catches of Newfoundland trawlers in Div. 4R in January 1979 and 1980 indicated the dominance of age-groups 6-8 for males and age-groups 8-10 for females (Fig. 7). In fact, the fishery in 1980 depended on fewer age-groups than in the previous year, particularly males. The difference in age frequencies between males and females is similar to that observed in the survey data and may be explained by the difference in timing of maturity, as discussed previously.

TABLE 3. Nominal catches (metric tons) of Greenland halibut in the Gulf of St. Lawrence, 1966-81.

\begin{tabular}{rrrrr}
\hline Year & Div. 4R & Div. 4S & Div. 4T & Total \\
\hline 1966 & 86 & 153 & 126 & 365 \\
1967 & 46 & 167 & 152 & 365 \\
1968 & 100 & 469 & 120 & 689 \\
1969 & 248 & 345 & 209 & 802 \\
1970 & 381 & 496 & 235 & 1,112 \\
1971 & 300 & 450 & 204 & 954 \\
1972 & 199 & 379 & 105 & 683 \\
1973 & 216 & 431 & 116 & 763 \\
1974 & 167 & 752 & 92 & 1,011 \\
1975 & 195 & 1,102 & 247 & 1,544 \\
1976 & 517 & 1,367 & 135 & 2,019 \\
1977 & 1,108 & 2,298 & 555 & 3,961 \\
1978 & 1,344 & 3,549 & 1,354 & 6,247 \\
1979 & 2,920 & 1,889 & 3,982 & 8,791 \\
1980 & 1,631 & 2,063 & 3,312 & 7,006 \\
1981 & 526 & 803 & 1,847 & 3,176 \\
\hline
\end{tabular}




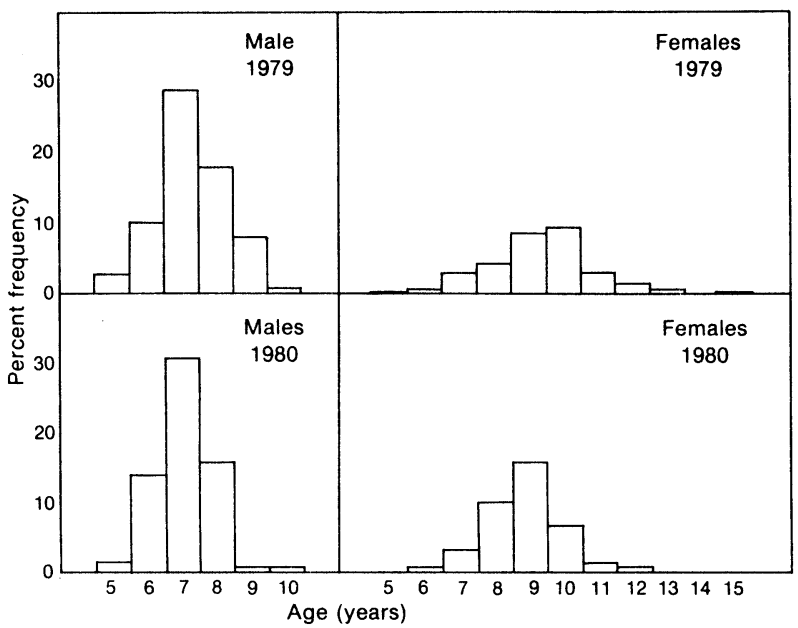

Fig. 7. Age compositions of commercial catches of male and female Greenland halibut in the Gulf of St. Lawrence, based on sampling of the winter fishery in 1979 and 1980.

Until 1982, there were no catch limitations for Greenland halibut in the Gulf of St. Lawrence. The Canadian Atlantic Fisheries Scientific Advisory Committee has indicated that, until the relationship between this stock and the Labrador-eastern Newfoundland is known, catch limitations on the Greenland halibut fishery in the Gulf may result in unnecessary loss of yield, particularly if the fishery is primarily supported by immigrants from the Labradoreastern Newfoundland stock which later emigrate there or elsewhere without contributing to future recruitment in the Gulf. The estimated reduction in minimum trawlable biomass is nearly 12,000 tons from 1978 to 1980 (Table 1), with recorded catches totalling about 15,000 tons over the same period (Table 3 ). The biomass further declined by about 6,800 tons from 1980 to 1981 , compared with a catch of 7,000 tons in 1980. The year-classes which formed the basis of these catches are now relatively unimportant, and there are at present no year-classes abundant enough to maintain the fishery at the catch levels of 1978-80. Without significant recruitment to the fishery, catches will likely continue to decline to levels prevalent prior to 1975.

\section{References}

BOWERING, W. R. 1976. Distribution, age and growth, and sexual maturity of witch flounder, Glyptocephalus cynoglossus, in the Newfoundland waters. J. Fish. Res. Bd. Canada, 33: 1574-1584.
1978. Age and growth of Greenland halibut, Reinhardtius hippoglossoides (Walbaum), in ICNAF Subareas 2-4. ICNAF Res. Bull., 13: 5-10.

1980. Fecundity of Greenland halibut, Reinhardtius hippoglossoides (Walbaum), from southern Labrador and southeastern Gulf of St. Lawrence. J. Northw. Atl. Fish. Sci., 1: 39-44.

MS 1980. Stock assessment and abundance of Greenland halibut in the Canadian North Atlantic (Subarea 2 and Divisions $3 \mathrm{~K}$ and 3 L). NAFO SCR Doc., No. 96, Serial No. N151.

BOWERING, W. R. 1983. Age, growth and sexual maturity of Greenland halibut (Reinhardtius hippoglossoides) in the Canadian Northwest Atlantic. Fish. Bull., U. S. (In press).

BOWERING, W. R., and W. B. BRODIE. MS 1981. Stock assessment of Greenland halibut in NAFO Subarea 2 and Divisions 3KL with projected catches for 1982. NAFO SCR Doc., No. 64, Serial No. N348

BOWERING, W. R., and R. K. MISRA. 1982. Comparisons of witch flounder, Glyptocephalus cynoglossus, stocks of the Newfoundland-Labrador area, based upon a new multivariate analysis method for meristic characters. Can. J. Fish. Aquat. Sci., 39 564-570.

BOWERS, A. B. 1960. Growth of the witch (Glyptocephalus cynoglossus) in the Irish Sea. ICES J. Cons., 25: 168-176.

DOUBLEDAY, W. G. (ed.). 1981. Manual on groundfish surveys in the Northwest Atlantic. NAFO Sci. Coun. Studies, 2, $55 \mathrm{p}$.

FAIRBAIRN, D. J. 1981. A biochemical genetic analysis of population differentiation in Greenland halibut, Reinhardtius hippoglossoides (Walbaum), from the Northwest Atlantic, Gulf of St. Lawrence and the Bering Sea. Can. J. Fish. Aquat. Sci., 38: 782-794.

FISHER, R. A., and F. YATES. 1953. Statistical tables for biological agricultural and medical research. Oliver and Boyd, London, 4th ed., $126 \mathrm{p}$.

FLEMING, A. M. 1960. Age, growth and sexual maturity of cod, Gadus morhua L., in the Newfoundland area, 1947-50. J. Fish. Res. Bd. Canada, 17: 775-809.

KHAN, R. A., M. DAWE, R. BOWERING, and R. K. MISRA. 1982. Blood protozoa as an aid for separating stocks of Greenland halibut, Reinhardtius hippoglossoides, in the Northwest Atlantic. Can. J. Fish. Aquat. Sci., 39: 1317-1322.

LUSSIAA-BERDOU, J. P. MS 1979. Evaluation récente de la population du Flétan du Gröenland (Reinhardtius hippoglossoides) et de sa peche dans le Golfe du St. Laurent. Can. Atl. Fish. Sci. Adv. Committee Res. Doc., No. 79/48, 10 p.

PITT, T. K. 1966. Sexual maturity and spawning in the American plaice, Hippoglossoides platessoides (Fabricius), from Newfoundland and Grand Bank areas. J. Fish. Res. Bd. Canada, 23: 651-672.

ROFF, D. A. 1980. A motion for the retirement of the von Bertalanffy function. Can. J. Fish. Aquat. Sci., 37: 127-129

TEMPLEMAN, W. 1970. Vertebral and other meristic characteristics of Greenland halibut, Reinhardtius hippoglossoides, from the Northwest Atlantic. J. Fish. Res. Bd. Canada, 27; 1549-1562.

1973. Distribution and abundance of the Greenland halibut, Reinhardtius htppoglossoides (Walbaum), in the Northwest Atlantic. ICNAF Res. Bull., 10: 82-98.

TEMPLEMAN, W., V. M. HODDER, and R. WELLS. 1978. Sexual maturity and spawning in haddock, Melanogrammus aeglefinus, of the southern Grand Bank. ICNAF Res. Bull., 13: 53-65.

TREMBLAY, C., and F. AXELSEN. MS 1981. Analyse de la population de Flétan du Gröenland du Nord-ouest du Golfe de Saint Laurent (4S, 4T). Can. Atl. Fish. Sci. Adv. Committee Res. Doc., No. 81/26, $24 \mathrm{p}$. 
